\section{A FOLK TAXONOMY OF TERMS FOR GHOSTS AND SPIRITS IN THAI ${ }^{1}$}

\section{Manasikarn Hengsuwan ${ }^{2}$ Amara Prasithrathsint ${ }^{3}$}

\section{บทคัดย่อ}

งานวิจัยส่วนใหญ่ ในอดีตมุ่งศึกษาบทบาทของผีใน สังคม และแสดงให้เห็นว่าวิถีชีวิตของคนไทยผูกพัน อยู่กับผีตั้งแต่เกิดจนกระทั่งตาย ยังไม่มีผลงานใดที่ ศึกษา “ผี” เพื่อตีแผผ่มโนทัศน์ของคนไทยอย่างเป็น ระบบ ดังนั้น งานวิจัยนี้จึงมีวัตถุประสงค์เพื่อ วิเคราะห์ระบบคำเรียกผี จัดจำพวกประเภทคำเรียกผี และตีความโลกทัศน์ของคนไทย ที่สะท้อนผ่าน ความหมายของคำเรียกผี โดยใช้วิธีที่เรียกว่า “การ จัดจำพวกแบบชาวบ้าน" ซึ่งเป็นวิธีวิเคราะห์อย่าง หนึ่งในอรรถศาสตร์ชาติพันธุ์

“"การจัดจำพวกแบบชาวบ้านของคำเรียกผีในภาษาไทย" An earlier version of this paper was presented at the $18^{\text {th }}$ Annual Conference of the Southeast Asian Linguistics Society (SEALS XVIII) held at Universiti Kebangsaan, Malaysia (21-22 May 2008). We would like to thank Nick Enfield, Kitima Indrambarya and Imran Ho Abdullah for their valuable comments and suggestions.

2 (มนสิการ เฮงสุวรรณ) Ph.D. Candidate,

Department of Linguistics, Faculty of Arts, Chulalongkorn University

3 (อมรา ประสิทธิ์รัฐสินธุ์) Emeritus Professor, Department of Linguistics, Faculty of Arts, Chulalongkorn University, Bangkok, Thailand
ผู้วิจัยเก็บข้อมูลด้วยการสัมภาษณ์ผู้บอกภาษาจำนวน 15 คน ซึ่งถูกคัดเลือกอย่างเฉพาะเจาะจงจากชาวบ้าน ในชุมชนวัดสวนแก้ว ตำบลบางเลน อำเภอบางใหญ่ จังหวัดนนทบุรี ซึ่งถือเป็นตัวแทนทางความคิดของ ผู้พูดภาษาไทยส่วนใหญ่ ผลการศึกษาพบประเภทผี ทั้งหมด 49 ประเภท ซึ่งจัดจำพวกแบบชาวบ้าน ออกเป็น 5 ระดับชั้น คือชั้นจุดเริ่มหนึ่งเดียว ชั้น รูปแบบชีวิต ชั้นบอกหมวด ชั้นเฉพาะเจาะจง และ ชั้นชนิดย่อย โดยชั้นจุดเริ่มหนึ่งเดียวมีคำเรียกผีเพียง คำเดียวคือ ผี (1) ซึ่งมีความหมายกว้างมากที่สุด ชั้น รูปแบบชีวิตมีคำเรียกผี 2 คำ คือ ผี (2) และ วิญญาณ สำหรับชั้นบอกหมวดมีคำเรียกผี 7 คำ เช่น ผีสางเทวดา กระสือ ปอบ ส่วนชั้นเฉพาะเจาะจงเป็น ระดับชั้นที่อยู่ภายใต้ชั้นบอกหมวดมีคำเรียกผีอยู่มาก ที่สุดคือ 33 คำ เช่น นางไม้ ผีป่า เปรต ระดับชั้น สุดท้ายคือชั้นชนิดย่อยมีคำเรียกผี 6 คำ เช่น เจ้าแม่ไทร เจ้าแม่มะขาม นางตานี

ผลการวิเคราะห์ความหมายของคำเรียกผีแสดงให้เห็น ว่าผู้พูดภาษาไทยคิดว่าผีมีวิถีการดำรงอยู่เหมือนคน ผี ส่วนใหญ่มีรูปร่างเหมือนคน และผีบางประเภทก็ยังมี ความเป็นคนอยู่ ผีแต่ละประเภทถูกจำแนกออกจาก กันด้วยพฤติกรรมการทำความดี ความชั่ว เพศ อายุ ที่ อยู่อาศัย และอาหารที่ผีกิน นอกจากนี้ ผลการวิจัยยัง แสดงให้เห็นว่าคนไทยมีทัศนคติทางลบต่อผี คือเห็น ว่าผีเป็นสิ่งที่น่ากลัว น่ารังเกียจ ติดสินบนได้ อย่างไร ก็ตามผีก็มีบทบาทสำตัญในการควบคุมสังคม 


\begin{abstract}
Previous studies show that Thai people's ways of life and traditions from birth to death are related to ghosts. Most of the studies deal with the role of ghosts in Thai society but there has been no study on ghost terms in Thai, which would reflect the ghost system in Thai thoughts. Thus, this study aims to analyze the system and categorization of terms for ghosts and spirits in Thai. Folk taxonomy, which is a method in the ethnosemantic approach, has been adopted for the analysis.
\end{abstract}

Data elicitation of the meanings of Thai ghost terms was done at Wat Suan Kaew Community, Tambon Bang Len, Amphoe Bang Yai, Nonthaburi Province, as representative of the mainstream Thai community. Fifteen intentionally selected informants were interviewed. The result of the analysis shows that there are forty nine categories of ghosts and spirits in Thai. They are classified into a taxonomy of five hierarchical classes: unique beginner, life-form, generic, specific, and varietal. There is only one unique beginner term: ph亡̌i(1) 'ghost+spirit'. There are two life-form terms: phǐi(2) 'ghost' and winyaan 'spirit'. As for generic ghost terms under life form, there are seven. Thirty three specific ghost terms were found e.g., naay-máay 'female spirit of a tree", phǐi-pàa 'forest demon', prèet 'evil tall spirit', etc. There are six sub-specific or varietal ghost terms, such

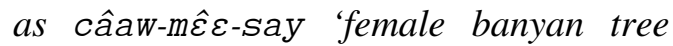

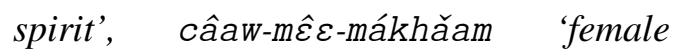
tamarind tree spirit', naay-taanii 'female banana tree spirit', etc.

It should be noted that Thai people conceive of ghosts as human. Indeed, most types of ghosts have a human shape and some even are human. Thai ghosts are distinguished by their kindness or malevolence, sex, age, dwelling place and the food they take.

Furthermore, it has been found that Thai people have negative attitudes towards ghosts as can be seen from the meanings of ghost terms. They find ghosts frightening, disgusting, and susceptible to bribes or dogged with misfortune as a result of karma. However, ghosts are seen as a means of controlling society.

\section{Introduction}

Previous studies have shown that the Thai daily way of life is related to their belief in ghosts from the time they are born to the time they die. Phaithayawatthana (1995: 91) states that Thai people believe that ghosts are in everything and that human beings belong to certain ghosts even before they are born. Some believe that powerful ghosts invent a human body through magic and give life to it by catching an aimless soul, putting it into the body and bringing that live body to a mother's womb. There is, therefore, a Thai tradition called súu lûuk (meaning 'buying a child'), which has led to a ceremony in which a mother pretends to buy her newborn baby from a ghost, otherwise, the ghost will take the newborn back in three days, and it will die if the parents have not observed the tradition. If the newborn can survive this period, it will thrive. This belief underlies the saying: "A newborn belongs to a ghost for three days and to a human being for four days" (Phaithayawatthana 1995: 95). Another tradition based on the belief in ghosts involves deceiving ghosts that the baby is not human or is too ugly to take. Thai people do this by making a comment on a newborn baby such as "What an ugly 
baby!" and naming their baby after an unpleasant thing or with an animal name, e.g. dam 'black', mûut 'dark', mǎa 'dog' and Pùn 'bullfrog,' etc. In addition, there is a tradition of performing a ceremony over a dead body to pacify the spirit and stop it from coming out and shocking humans. This is based on the belief that when a human being dies, it will be transformed into a living ghost.

The oldest written record that serves as evidence showing the Thai belief in ghosts is 716 years old. It is the first stone inscription of the Sukhothai period (12381438) that says the following:

"In the North of Sukhothai city, there is a entity where a scholarly monk lives in, a barrage, a forest of coconut and areca palms, mango and tamarind trees, and water resources. There is also prá-khàphuy-ph $\check{i}{ }^{4}$ in that mountain. It is more powerful than the other ghosts in the city. If a ruler offers worship to it, the city will prosper. If not, the city will not be protected and finally, will face a catastrophe."

(The Fine Arts Department 1984)

The above quotation signifies that Sukhothai people made offerings to prákhàphuy-ph亡̈i, the leader of ghosts and spirits in the Sukhothai City in order that it would protect them and allow them to live peacefully. It is generally accepted that after Brahmanism and Buddhism came to the city, their doctrines and practices harmonized with the tradition of worshipping ghosts and spirits as can be seen in several religious ceremonies in

4 prá-khàphuy-phǐi means 'the most powerful spirit.'
Thai people's everyday life; for example, Buddhist ceremonies of offering alms to monks, making merit and funeral rites, etc., and Brahman ceremonies of establishing a spirit house, offering rice and summoning one's spirit (khwăn) to stay in and protect one's body. This ceremony is called baaysǐi-sùu-khwăn and rites about ghosts, e.g. house-blessing and ghost-feeding ceremonies.

Obviously, the more roles ghosts have played in everyday life, the more terms for them are to be found in the Thai language. However, although it is observed that there are many ghost terms in Thai, nobody knows how many there are, exactly, how they are categorized in Thai cognition and what each category specifically denotes and connotes.

All of the questions above make it necessary to study terms for ghosts and spirits in Thai thoroughly and systematically. This study, therefore, is an attempt to analyze such terms using an ethnosemantic approach, which according to Prasithrathsint (2006: 79), means arriving at a people's way of thinking and worldview through the study of the meanings of certain words in their language. In this study, the meanings of the terms for ghosts and spirits were analyzed from the native Thai viewpoint and were finally categorized into a taxonomic system. Also, from the denotations and connotations of the terms, the concepts of "ghost" and "spirit" in Thai cognition are clearly depicted and Thai attitudes toward ghosts are inferred.

Folk taxonomy has been used in ethnosemantic studies for classifying the indigenous system of categorization. Frake (1961: 115) analyzed disease terms in Subanun in the Philippines. He found that 
the diagnostic category was labelled by the disease name. On the other hand, several diseases names might indicate just a single illness. So, Subanun speakers had to use these medical terms carefully, otherwise the others would not understand what they wanted to describe. Frake (1961) said that the Subanun's disease concepts were different from Western ones. Berlin (1992) and Berlin, Breedlove, and Raven (1973) studied folk biology and proposed that there were five universal ethnobiological hierarchical categories: unique beginner, life form, generic, specific and varietal (See definitions of these terms below). Indeed, a number of studies applied the folk taxonomy approach to the classification of Thai cultural terms. For example, Pumyoo (2005) compared the systems of rice classification in Southeast Asian languages, including Thai, using folk taxonomy, and Panyaatisin (2009) showed the result of his analysis of the system of cooking terms in Northern Thai dialect through a folk taxonomy.

In the present study, the data used in the analysis consisted of terms for ghosts and spirits and their meanings. The terms were taken from fiction and non-fiction concerned with mystery, magic, and superstition. The meanings of the terms were elicited through interviews with fifteen informants, who were deliberately selected from the Wat Suan Kaew Community, Tambon Bang Len, Amphoe Bang Yai, Nonthaburi Province, which was generally regarded as representative of a regular community of mainstream Thai people. The informants were native speakers of Standard Thai who had lived in that community since birth and were over fifty years old. They had completed compulsory education; i.e., level 4 in elementary school. Among the fifteen informants, eleven of them were orchardists, and the rest had been hired to do odd jobs in the community. They were all native speakers of Thai who lived in a Thai cultural environment with very little or no influence from other cultures. Thus, the information elicited from them would be expected to lead us to a knowledge and understanding of the Thai way of thinking related to ghosts and spirits.

In the process of data collection, at first we collected all the terms signifying any kind of supernatural being. Later on, however, only traditional ghost terms in Standard Thai were adopted for analysis. Therefore, terms in other dialects and recently created terms that signified ghosts of utensils, such as shampoo ghosts, soap ghosts, refrigerator ghosts, air-conditioner ghosts, etc., were removed from the list. Ultimately, there were altogether fifty six terms used in the analysis. Ideally, one term should represent one conceptual category, but we found that those fifty six terms represented only forty nine ghost categories. The reason for the discrepancy between the number of terms and categories represented by the terms was that, in some cases, more than one term represented a single category. All the terms can be seen in Table1.

\section{A folk taxonomy of Thai ghost terms}

The results of the analysis of the meanings of all the ghost terms mentioned above enabled us to categorize all the terms and arrange them into a hierarchical folk taxonomy. We adopted Berlin's technical terms representing levels in taxonomy (Berlin 1992). He proposed five levels in the ethnobiological classification of plants and animals in traditional societies: unique 
beginner, life form, generic, specific and varietal.

These five significant concepts seem to be most applicable to the classification of ghost terms. Unique Beginner is the topmost level of the hierarchy. It is the highest and most inclusive rank consisting of only one term that includes every term under it. The second is life form meaning the body form representing a kind of organism. Even though we are not sure whether all would agree that ghosts and spirits are organisms, we think that the term life form is applicable to an identifiable category of a group of supernatural things. The main principles of a folk taxonomy are contrast and inclusion. This means that each term is in contrast with others at the same level and is included in the term at the above level. Thus life forms contrast with one another and are included in unique beginner. At the same time, under life form there are other terms included. This level is called generic meaning general class or group. This term also suits the classification of ghosts and spirits in Thai in terms of describing a general class in which there are many sub-categories, labeled by Berlin (1992) as specific, meaning a special or particular class. As will be seen later, some ghost terms are particular and can be grouped under generic. The last level is varietal, here meaning something that deviates from a specific kind. Thus, varietal is included in specific. The varietal level is the lowest of the taxonomy. Below is a folk taxonomy of ghost terms in Thai. 
Table 1: folk taxonomy of ghost terms in Thai

\begin{tabular}{|c|c|c|c|c|}
\hline $\begin{array}{c}\text { Unique } \\
\text { beginner }\end{array}$ & $\begin{array}{l}\text { Life } \\
\text { form }\end{array}$ & Generic & Specific & Varietal \\
\hline \multirow{32}{*}{ 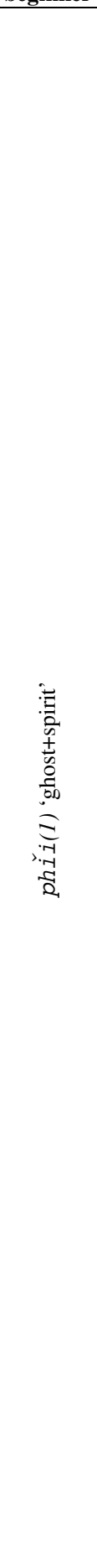 } & \multirow{32}{*}{ 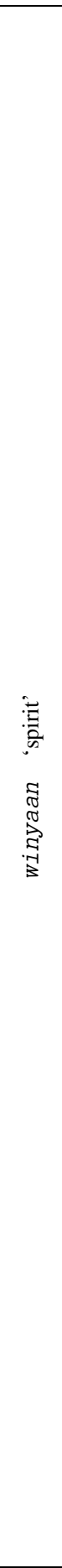 } & \multirow{15}{*}{ 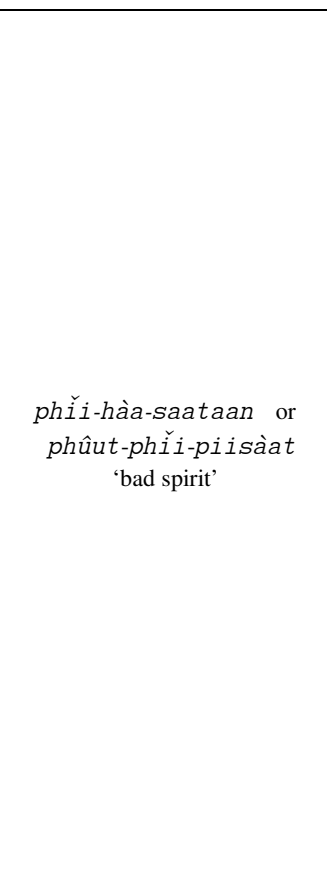 } & \multirow{4}{*}{ naay-máay 'female spirit of a tree' } & 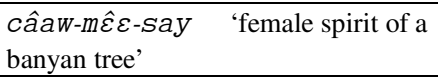 \\
\hline & & & & 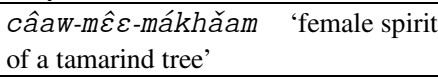 \\
\hline & & & & $\begin{array}{ll}\text { naay-taanii } & \text { 'female spirit of a } \\
\text { banana tree' } & \\
\end{array}$ \\
\hline & & & & $\begin{array}{l}\text { naay-tàkhian 'female spirit of a } \\
\text { ta-khian tree' }\end{array}$ \\
\hline & & & phǐi-nûak 'mermaid ghost' & \\
\hline & & & phǐi-pàa $\quad$ 'jungle demon' & \\
\hline & & & phǐi-thalee 'sea ghost' & \\
\hline & & & $\begin{array}{l}\text { phǐi-náam or phǐi -praay or praay- } \\
\text { náam 'water ghost' }\end{array}$ & \\
\hline & & & $\begin{array}{l}\text { phǐi-taay-thán-klom or phǐi-taay- } \\
\text { thóon-klom 'female ghost dying during } \\
\text { pregnancy' }\end{array}$ & \\
\hline & & & prèet 'tall evil ghost' & \\
\hline & & & yommabaan 'the chief guardian of hell' & \\
\hline & & & yommathûut 'guardian of hell' & \\
\hline & & & phǐi-rêerôn 'stray ghost' & \\
\hline & & & phǐi-hàa 'bad spirit causing epidemic' & \\
\hline & & & piisàat 'devil' & \\
\hline & & $\begin{array}{l}\text { phǐi-săan-theewadaa } \\
\text { 'good spirit' }\end{array}$ & $\begin{array}{l}m \hat{\varepsilon} \mathcal{\varepsilon}-y a ̂ a-n a a \eta \\
\text { 'female guardian spirit of a boat' }\end{array}$ & \\
\hline & & & $\begin{array}{l}\text { thee-phaa-ráak or rúk-khà- } \\
\text { theewadaa } \\
\text { 'male guardian spirit of a tree' }\end{array}$ & \\
\hline & & & $\begin{array}{l}\begin{array}{l}\text { pùu-sǒom 'old male guardian spirit of } \\
\text { treasure' }\end{array} \\
\end{array}$ & \\
\hline & & & câaw-khǎw 'spirit of a mountain' & \\
\hline & & & câaw-pàa $\quad$ 'spirit of a forest' & \\
\hline & & & $m \hat{\varepsilon} \varepsilon$-phoosòp $\quad$ 'goddess of rice' & \\
\hline & & & $m \hat{\varepsilon} \varepsilon-k h o \eta k h a a \quad$ 'goddess of a river' & \\
\hline & & & $m \hat{\varepsilon} \varepsilon$-thooranịi 'goddess of land' & \\
\hline & & & theewadaa 'angel' & $\begin{array}{l}\text { thêep-thídaa or naay-fáa } \\
\text { 'female deity' }\end{array}$ \\
\hline & & & & thêep 'male deity' \\
\hline & & & phrá-sûa-muıạ 'guardian spirit of a city’ & \\
\hline & & & câaw-phọọ'benevolent male spirit' & \\
\hline & & & 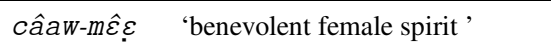 & \\
\hline & & & 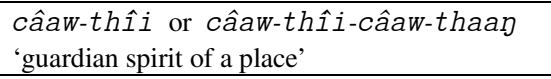 & \\
\hline & & & $\begin{array}{l}\text { phrá-phuum } \\
\text { 'male guardian spirit dwelling in a spirit house' }\end{array}$ & \\
\hline & & & phǏi-bâan-phǐi-ruaṇ’house spirit’ & \\
\hline & & & $\begin{array}{l}m \hat{\varepsilon} \mathcal{E} \text {-Súmu } \\
\text { infant' }\end{array}$ & \\
\hline
\end{tabular}




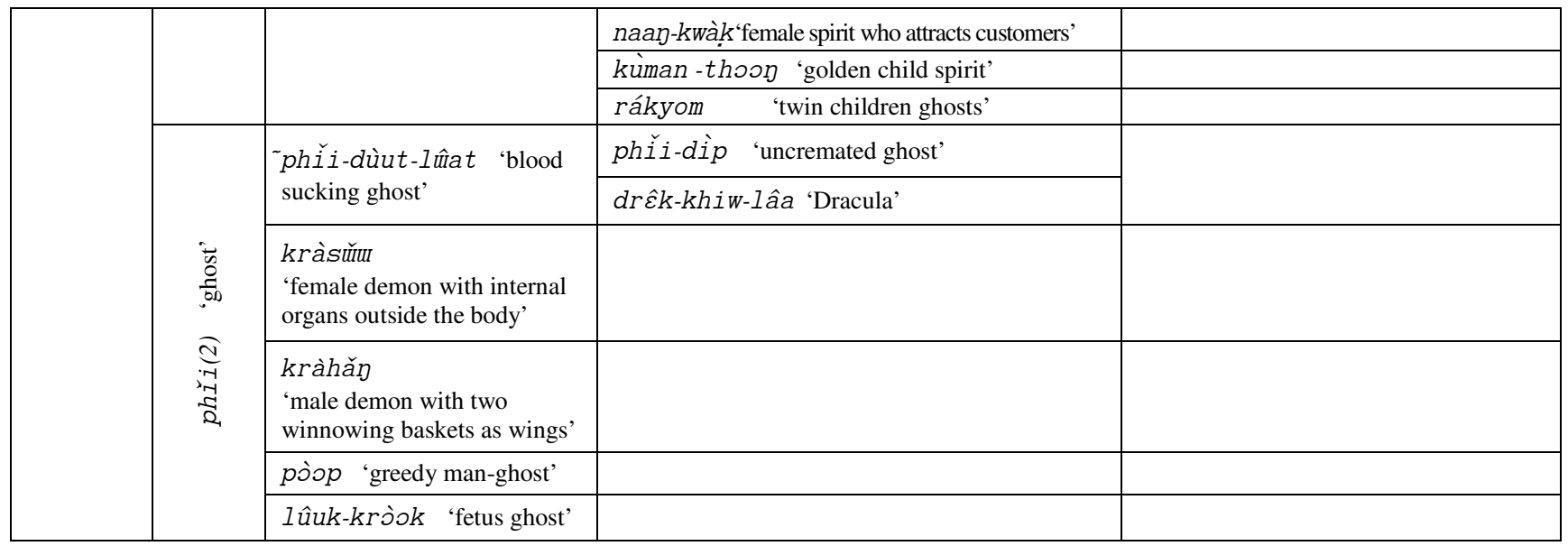

Table 2: the unique beginner ph亡̌i(1) 'ghost+spirit'

\begin{tabular}{|l|l|l|}
\hline \multicolumn{1}{|c|}{ Unique beginner } & \multicolumn{1}{|c|}{ English equivalent } & \multicolumn{1}{c|}{ Meaning } \\
\hline $\begin{array}{l}\text { ph } \check{i}(1) \\
\text { ผี (1) }\end{array}$ & 'ghost+spirit' & $\begin{array}{l}\text { A supernatural being manifested in any } \\
\text { form, which may be visible or invisible. }\end{array}$ \\
\hline
\end{tabular}

\section{The first level: unique beginner}

The unique beginner has the broadest meaning (See Table 2). It is represented by only one term: phïi(1) 'ghost+spirit'. Based on the analysis of traditional meanings and the informants' judgment, all the other ghost terms presented in this article are included in this level of unique beginner. Indeed, this unique beginner of ghost terms in Thai distinguishes between what is a ghost and what is not. Such terms as lǔay-pùu 'an old monk', sàdètphôo-roo-hâa 'King Rama the Fifth' are not ghost terms-none of the informants said they were, when they were asked "Is this (the term) ph $\check{i} i$ ?'.

It is important to note that the word pronounced [ph $\check{i} i]$ in Thai has two meanings, as shown in Tables 2 and 3 . The difference in meaning is significant with regard to the breadth of each denotation, which suggests a hierarchical difference. Thus, we conclude that there are two words in the same phonetic form: phíi(1), with the broader or more general meaning and phri(2), being the narrower in meaning.

The most general ghost term in Thai, the unique beginner phǐi(1), can be seen when it occurs in such sentences as (1) and (2).
(1) khǎw chûa rûay ph亡̌i(1) . he believe story ghost 'He believes in ghosts.'

(2) phǐi(1) pen sìn nâa-klua. ghost be thing terrifying 'Ghosts are terrifying things.' 


\section{The second level: life form}

Next in the taxonomy from the unique beginner is the life form level containing two terms: phǐi(2) 'ghost' and winyaan 'spirit'. They are in contrast with each other and are both immediate subcategories of the unique beginner. Analysis of the meanings of the terms (See Table 4) and the informants' judgment confirm this. All of the interviewees said both ph亡̌i(2) 'ghost' and winyaan 'spirit' are included in phǏi(1) 'ghost+ spirit.'

Table 3: life forms phǐi(2) 'ghost' and winyaan 'spirit'

\begin{tabular}{|l|l|l|}
\hline \multicolumn{3}{|c|}{ Unique beginner: $p h \check{i}$ i (1) 'ghost+spirit' } \\
\hline \multicolumn{1}{|c|}{ Life form } & $\begin{array}{l}\text { English } \\
\text { equivalent }\end{array}$ & \multicolumn{1}{c|}{ Meaning } \\
\hline $\begin{array}{l}\text { ph亡̌i(2) } \\
\text { ผี(2) }\end{array}$ & 'ghost' & $\begin{array}{l}\text { A supernatural being } \\
\text { transformed from a } \\
\text { deceased person or animal. } \\
\text { It is visible and touchable } \\
\text { and can appear in any } \\
\text { shape. (opposite to } \\
\text { winyaan 'spirit') }\end{array}$ \\
\hline $\begin{array}{l}\text { winyaan } \\
\text { วิญญาณ }\end{array}$ & 'spirit' & $\begin{array}{l}\text { A spirit, which is } \\
\text { intangible, invisible and has } \\
\text { no identifiable form. } \\
\text { (opposite to ph } \check{i} i(2) \\
\text { 'ghost') }\end{array}$ \\
\hline
\end{tabular}

These two terms in the second level occur in such sentences as (3) and (4).

(3) phĩi-kràsŭu pen phii(2)
Krasue be ghost
thĩi raw mooł hĕn dâay.
that we look see can

'Krasue is a ghost that we can see.'
(4) phûuchaay khon nán Pàat

man person that may

pen phǐi(2) phró chôop

be ghost because(he) likely

hăay pay toon khlan kuun.

Disappear away at middle night

'That man may be a ghost because he is likely to disappear at night.'

$$
\begin{aligned}
& \text { (5) chăn moon mây hěn } t \grave{\varepsilon} \varepsilon \\
& \text { I look not see but } \\
& \text { rúu-sùk wâa winyaan } \\
& \text { feel that spirit } \\
& \text { khun-taa yùu thîi-nîi. } \\
& \text { grandfather be here } \\
& \text { 'I cannot see it but feel that my } \\
& \text { grandfather's spirit is here.' }
\end{aligned}
$$

\section{The third level: generic}

The third level in the folk taxonomy of ghost terms in Thai is the generic level, which is under life form. There are eight terms representing seven categories at this level. Three of them; namely, phǐi-sǎantheewadaa 'good spirit', ph亡̌i-hàasaataan and phût-phíi-piisàat, both meaning 'bad spirit' are under winyaan 'spirit' in the second level. The rest are five terms representing ghost categories under phíi(2) 'ghost,' which contrasts with winyaan 'spirit.' The five categories share one important characteristic; i.e., they are ghosts that are visible and touchable. Actually, we can say that they are humans who have become ghosts. For example, kràsǔu is a human being who has become a ghost. At night, she usually goes out of her house and roams in the surroundings to find rotten things to feed on. Most of the time she appears and behaves as a normal human being. The meanings of the generic categories can be seen in Table 4 and Table 5 below. 
Table 4: generic ghost categories under the life form winyaan 'spirit'

\begin{tabular}{|c|c|c|}
\hline \multicolumn{3}{|c|}{ life form: wi nyaan 'spirit' } \\
\hline Generic & English equivalent & Meaning \\
\hline $\begin{array}{l}\text { phǐi-sǎan- } \\
\text { theewadaa } \\
\text { ผีสางเทวดา }\end{array}$ & 'good spirit' & $\begin{array}{l}\text { A good spirit who brings fortune and prosperity to } \\
\text { man. It does not do harm or cause trouble to man. }\end{array}$ \\
\hline $\begin{array}{l}\text { phǐi-hàa- } \\
\text { saataan } \\
\text { ผีห่าซาตาน or } \\
\text { phûut-phǐi- } \\
\text { piisàat } \\
\text { ภูติผีปีศาจ }\end{array}$ & 'bad spirit' & $\begin{array}{l}\text { A dreadful wicked spirit who causes sufferings and } \\
\text { all sorts of trouble. }\end{array}$ \\
\hline
\end{tabular}

Table 4 shows two generic terms under winyaan 'spirit' in the life form level. They are long compound words with collective meanings. The first one is composed of three words: ph亡̌i meaning 'ghost,' săay also meaning 'ghost,' (archaic), and theewadaa meaning 'angel.' Altogether, the compound means collectively 'good spirit.' The term

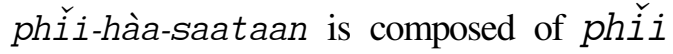
meaning 'ghost,' hàa meaning 'bad spirit causing an epidemic' and saataan 'devil' The whole compound means 'bad spirit.' The last one phût-phíi-piisàat is composed of phûut 'demon,' phři 'ghost,' and piisàat meaning 'devil.' The compound means exactly the same as phíi-hàa-saataan. They both denote the same category of 'bad spirit.'

The following are examples of sentences in which the above generic terms occur (Examples 6, 7, 8).

(6) khǒohây phǐi-săan theewadaa

ask good spirit

khúm-khroon phûak-raw.

protect we

'May good spirits protect us!'
(7) khon thay baay khon chûa person Thai some person believe wâa rûay leew-ráay

that happening bad thán-lăay kł̀rt càak kaan all born from NOMINAL kràtham khǒon action of phûut-phǐi-piisàat rǔu Bad spirit or sìn nǔa thammachâat. thing above nature 'Some Thai people believe that all bad things are caused by bad spirits or supernatural things.'

\section{(8) phǐi-hàa saataan ton day} Bad spirit person which don-bandaan hây khun tham chûa inspire give you do evil 'Which bad spirit inspired you to do evil things?' 
Table 5: generic ghost categories under the life form ph亡̌ $i(2)$ 'ghost'

\begin{tabular}{|c|c|c|}
\hline \multicolumn{3}{|c|}{ life form: $p h \check{i} i(2)$ 'ghost' } \\
\hline Generic & English equivalent & Meaning \\
\hline $\begin{array}{l}\text { kràsǔu } \\
\text { กระสือ }\end{array}$ & $\begin{array}{l}\text { 'female demon with } \\
\text { internal organs } \\
\text { outside the body' }\end{array}$ & $\begin{array}{l}\text { A woman who has become a demon whose body } \\
\text { consists merely of a head and internal organs, } \\
\text { such as the heart, the lungs, the intestines. She can } \\
\text { emit a gloomy green light during the night while } \\
\text { feeding herself. Her food is raw meat, excrement, } \\
\text { fresh placenta and dirty things. }\end{array}$ \\
\hline $\begin{array}{l}\text { kràhǎy } \\
\text { กระหัง }\end{array}$ & $\begin{array}{l}\text { 'male demon with } \\
\text { two winnowing } \\
\text { baskets as wings' }\end{array}$ & $\begin{array}{l}\text { A man who has become a demon who feeds on } \\
\text { excrement, dirt and the fresh entrails of a dead } \\
\text { body. He has two wings made of winnowing } \\
\text { baskets (kràdôn). }\end{array}$ \\
\hline $\begin{array}{l}\text { pう̀op } \\
\text { ปอบ }\end{array}$ & 'greedy man-ghost' & $\begin{array}{l}\text { A male or female who is believed to become a } \\
\text { ghost that is very greedy and feeds on fresh } \\
\text { entrails, dead bodies and live animals. }\end{array}$ \\
\hline $\begin{array}{l}\text { phíi-dùut- } \\
\text { lûat ผีดูดเลือด }\end{array}$ & 'blood sucking ghost' & $\begin{array}{l}\text { A human who has become a ghost which is } \\
\text { believed to feed on fresh blood. }\end{array}$ \\
\hline $\begin{array}{l}\text { lûuk- } \\
\text { kròok } \\
\text { ลูกกรอก }\end{array}$ & 'fetus ghost' & $\begin{array}{l}\text { A premature baby who dies when it is born and } \\
\text { becomes a tiny ghost. It is believed that if people } \\
\text { worship it, it will bring them luck, and, in } \\
\text { contrast, it can bring them misfortune if it is not } \\
\text { satisfied. }\end{array}$ \\
\hline
\end{tabular}

The five terms under ph亡̌i(2) 'ghost' represent five categories of ghosts that share one important characteristic; i.e., they are humans who have become ghosts. kràsǔur (female) and kràhăn (male) are human beings who have become ghosts. At night, they usually go out to find food. Examples of using the words kràsǔu (female) and kràhăy (male) are as follows.

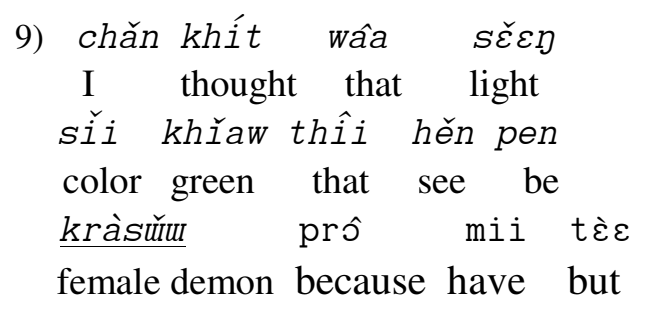

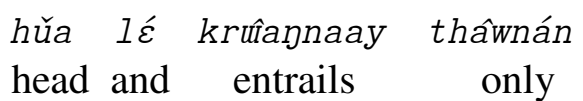

'I am absolutely sure that the green light is kràsǔm because there is only a head and entrails.'

(10) kràhăn tii pìk
male demon hit wings
kràdôn looy
winnowing basket fly
nı̌i chawbâan.
escape villagers
'krà-hăn flies away with his
winnowing basket wings.'


Similarly, pjop is a human who has become a ghost that eats greedily. It can be anyone in the family who turns into pذ̀op, as in (11).

(11)

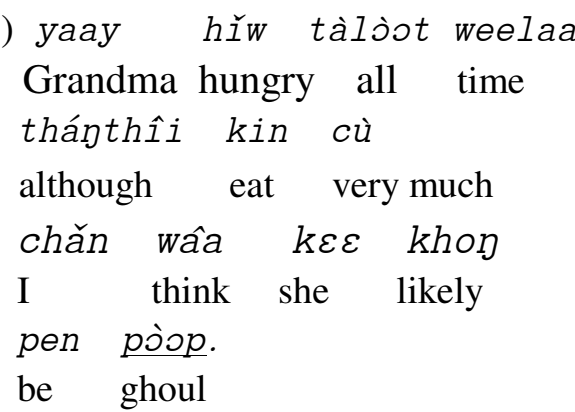

'Grandma/old woman is hungry all the time though she eats a lot. I think she is probably a pòop.'

As for phíi-dùut-lûat, it is a human that has become a blood-sucking ghost, as shown in (12).

(12)

$$
\begin{aligned}
& \text { thrr khoy thùuk } \\
& \text { you might passive } \\
& \text { phři-dùut lûat }
\end{aligned}
$$

ghost that drinks people's blood

kàt $n \hat{\varepsilon \varepsilon}$ pró tua sît

bite sure because body pale

lé mii rooy khî̀aw sǒon

and have scar teeth two

sii bon khoo.

piece on neck

'You might have been bitten by phǐi-dùut-lûat because your

body is pale and there is a two-teeth bite scar on your neck.'

(13) chăn lían lûukkròok

I have raised foetus ghost

mǔan lûuk chăn phûut

like child I speak

khàp khăw b̉̀̀-b’̀̀

with him often
'I have raised the foetus ghost like my child. I speak to him often.

\section{The fourth level: specific}

In this section, we will show specific terms under the generic level. Altogether thirty three specific ghost categories were found. Nineteen specific categories are under phǐi-săan-theewadaa 'good spirit', twelve under ph亡̌i-hàasaataan or phuutt-phǐi-piisàat 'bad spirit,' and two under phrii-dùutlûat 'blood sucking ghost.' Table 6 shows the specific categories under the generic phíi-săan-theewadaa 'good spirit', Table 7 shows those under ph ̌i hàa-saataan or phûut-ph亡̌i-piisàat 'bad spirit,' and Table 8 shows the two categories under phǐi-dùut-lûat 'blood sucking ghost.' 
MANUSYA: Journal of Humanities Regular 17.2, 2014

Table 6: Specific ghost categories under the generic ph ̌̌i-săaĐ-theewadaa 'good spirit'

\begin{tabular}{|c|c|c|}
\hline \multicolumn{3}{|c|}{ Generic: phǐi-sǎay-theewadaa 'good spirit' } \\
\hline Specific & English equivalent & Meaning \\
\hline $\begin{array}{l}m \hat{\mathcal{E} \varepsilon}-\text { yâa-naay } \\
\text { แม่ย่านาง }\end{array}$ & $\begin{array}{l}\text { 'female guardian } \\
\text { spirit of a boat' }\end{array}$ & $\begin{array}{l}\text { The goddess guardian of boats, carts, cars } \\
\text { and other vehicles. Those who believe in this } \\
\text { ghost need to offer bribes and colorful } \\
\text { garments to her so that she will protect them. }\end{array}$ \\
\hline $\begin{array}{l}\text { theephaa-ráak } \\
\text { เทพารักษ์ or rúkkhà- } \\
\text { theewadaa รุกขเทวดา }\end{array}$ & $\begin{array}{l}\text { 'male guardian spirit } \\
\text { of a tree' }\end{array}$ & $\begin{array}{l}\text { A spirit dwelling in a particular tree in the } \\
\text { forest who is in charge of protecting trees } \\
\text { from being cut by humans. }\end{array}$ \\
\hline $\begin{array}{l}\text { pùu-sǒom } \\
\text { ปู่โสม }\end{array}$ & $\begin{array}{l}\text { 'old male guardian } \\
\text { spirit of treasure' }\end{array}$ & $\begin{array}{l}\text { The spirit of a very old man who is believed } \\
\text { to be unable to leave his possessions. } \\
\text { Therefore, it has to guard his property } \\
\text { forever. }\end{array}$ \\
\hline $\begin{array}{l}\text { câaw-khǎw } \\
\text { เจ้าเขา }\end{array}$ & 'spirit of a mountain' & $\begin{array}{l}\text { A spirit who is more powerful than other } \\
\text { spirits in a particular mountain. Most people } \\
\text { who pass by have to bribe or pay respect to it } \\
\text { so as to be protected from mysterious harm. } \\
\text { This term usually occurs with câaw-pàa } \\
\text { 'spirit of a forest' to form a semantic } \\
\text { doublet: câaw-pàa-câaw-khăw 'spirits of } \\
\text { forests and mountains' }\end{array}$ \\
\hline $\begin{array}{l}\text { câaw-pàa } \\
\text { เจ้าป่า }\end{array}$ & 'spirit of a forest' & $\begin{array}{l}\text { A spirit which has more special powers than } \\
\text { other neighboring spirits in a particular } \\
\text { forest. People who pass by have to offer to } \\
\text { pay respect to it so as to be protected from } \\
\text { mysterious harm. This term usually occurs } \\
\text { with câaw-khăw 'spirit of a mountain' to } \\
\text { form a semantic doublet: câaw-pàa-câaw- } \\
k \text { hǎw 'spirits of forests and mountains' }\end{array}$ \\
\hline $\begin{array}{l}m \hat{\mathcal{E}} \mathcal{\varepsilon}-p h o o s o ̀ p \\
\text { แม่โพสพ }\end{array}$ & 'goddess of rice' & $\begin{array}{l}\text { The female spirit which protects all paddy } \\
\text { rice fields. }\end{array}$ \\
\hline $\begin{array}{l}m \hat{\varepsilon} \mathcal{\varepsilon}-k h o \eta k h a a \\
\text { แม่คงคา }\end{array}$ & 'goddess of a river' & The female spirit which protects rivers \\
\hline $\begin{array}{l}m \hat{\varepsilon} \mathcal{E}-\text { thooranii } \\
\text { แม่ธรณี }\end{array}$ & 'goddess of land' & The female spirit which protects land. \\
\hline $\begin{array}{l}\text { theewadaa } \\
\text { เทวดา }\end{array}$ & 'angel' & $\begin{array}{l}\text { A male or female deity who has a beautiful } \\
\text { seductive body and dwells with joy in } \\
\text { heaven. He or she has more ability and } \\
\text { power than humans. }\end{array}$ \\
\hline
\end{tabular}




\begin{tabular}{|c|c|c|}
\hline $\begin{array}{l}\text { phrá-sûa-muạ } \\
\text { พระเสื้อเมือง }\end{array}$ & $\begin{array}{l}\text { 'guardian spirit of a } \\
\text { city’ }\end{array}$ & $\begin{array}{l}\text { A spirit who dwells at the main shrine of a } \\
\text { city. His duty is to guard the city. }\end{array}$ \\
\hline $\begin{array}{l}\text { câaw-phôo } \\
\text { เจ้าพ่อ }\end{array}$ & $\begin{array}{l}\text { 'benevolent male } \\
\text { spirit' }\end{array}$ & $\begin{array}{l}\text { A male spirit praised and bribed by believers } \\
\text { who think that he can bring them fortune, } \\
\text { prosperity or solve some difficulties they } \\
\text { have undergone. A Thai style shrine is often } \\
\text { established for his dwelling and as a symbol } \\
\text { of people's respect for him. }\end{array}$ \\
\hline $\begin{array}{l}c \hat{a} a w-m \hat{\varepsilon} \varepsilon \\
\text { เจ้าแม่ }\end{array}$ & $\begin{array}{l}\text { 'benevolent female } \\
\text { spirit' }\end{array}$ & $\begin{array}{l}\text { Similar to câaw-phôo 'benevolent male } \\
\text { spirit,' this term denotes a female spirit who } \\
\text { is praised and bribed by surrounding people } \\
\text { because they believe that she can bring them } \\
\text { fortune, prosperity or solve some difficulties } \\
\text { they have undergone. A Thai style shrine is } \\
\text { often built for her dwelling and as a symbol } \\
\text { of people's respect for her. }\end{array}$ \\
\hline 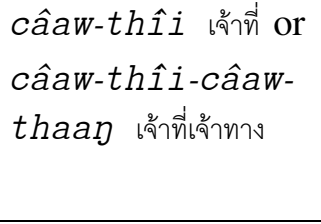 & $\begin{array}{l}\text { 'guardian spirit of a } \\
\text { place' }\end{array}$ & $\begin{array}{l}\text { A spirit that haunts a particular place } \\
\text { previously owned by him/her when he or she } \\
\text { was alive. It is believed that this demon } \\
\text { helps protect the place from bad spirits or } \\
\text { disasters. }\end{array}$ \\
\hline $\begin{array}{l}\text { phrá-phuum } \\
\text { พระภูมิ }\end{array}$ & $\begin{array}{l}\text { 'male guardian spirit } \\
\text { dwelling in a spirit } \\
\text { house' }\end{array}$ & $\begin{array}{l}\text { A respectable male spirit invited by the } \\
\text { owner of a place to dwell in a shrine (called } \\
\text { a "spirit house") in a yard. People believe } \\
\text { that this spirit will make them prosperous, } \\
\text { healthy and protect the house from } \\
\text { misfortune. }\end{array}$ \\
\hline $\begin{array}{l}\text { phǐi-bâan-phǐi- } \\
\text { ruan } \\
\text { ผีบ้านผีเรือน }\end{array}$ & 'house spirit' & $\begin{array}{l}\text { A spirit that protects a house, it is believed } \\
\text { that this spirit is the ancestor of the house's } \\
\text { owner. It protects all the members of the } \\
\text { house. }\end{array}$ \\
\hline $\begin{array}{l}m \hat{\varepsilon} \mathcal{\varepsilon}-\text {-SÚயu } \\
\text { แม่ซื้อ }\end{array}$ & $\begin{array}{l}\text { 'female spirit that } \\
\text { protects an infant' }\end{array}$ & $\begin{array}{l}\text { The spirit whose duty is to protect an infant } \\
\text { from any harm. It takes care of the baby until } \\
\text { it becomes two/three years old. }\end{array}$ \\
\hline $\begin{array}{l}\text { naay-kwàk } \\
\text { นางกวัก }\end{array}$ & $\begin{array}{l}\text { 'female spirit who } \\
\text { attracts customers' }\end{array}$ & $\begin{array}{l}\text { A female spirit represented by a miniature } \\
\text { figure poses by sitting and raising one of her } \\
\text { hands to beckon people. It is believed that } \\
\text { she can persuade customers to purchase } \\
\text { goods in the store or bring prosperity to the } \\
\text { owner who bribes her. }\end{array}$ \\
\hline $\begin{array}{l}\text { kùman -thoon } \\
\text { กุมารทอง }\end{array}$ & 'golden child spirit' & $\begin{array}{l}\text { A child spirit dwelling inside a miniature } \\
\text { childhood stucco or wooden figure. It is } \\
\text { believed that its owner needs to bribe it with } \\
\text { food or other things it likes. }\end{array}$ \\
\hline
\end{tabular}




\begin{tabular}{|l|l|l|}
\hline $\begin{array}{l}\text { rákyom } \\
\text { รักยม }\end{array}$ & $\begin{array}{l}\text { 'twin children } \\
\text { ghosts' }\end{array}$ & $\begin{array}{l}\text { The ghosts of twin children (one male, one } \\
\text { female) in the shapes of wooden carved } \\
\text { miniature twin figures. It is believed that } \\
\text { these doll ghosts feed on sandalwood oil and } \\
\text { work as guardians of people and their } \\
\text { houses. }\end{array}$ \\
\hline
\end{tabular}

As shown in Table 6, all the terms represent nineteen categories of 'good spirit,' but they differ in terms of gender. For example, The word câawphôo 'benevolent male spirit', pùusǒom 'old male guardian spirit of treasure' are male but $c a \hat{a} w-m \hat{\varepsilon} \varepsilon$ 'benevolent female spirit', $m \hat{\mathcal{E}} \mathcal{E}$-phoosòp 'goddess of rice', $m \hat{\varepsilon} \mathcal{E}$-súm 'female spirit that protects an infant' are female.

The dwelling place also distinguishes one specific ghost term from another. For example, theewadaa 'angel' resides in heaven, phrá-phuum 'a male guardian spirit of land' dwells in a spirit house, phǐi-bâan-phìi-ruan 'house spirit' resides in the house.

Age is another factor that differentiates specific ghost terms. While, people see the image of pùu-sǒom 'old male guardian spirit of treasure' as an old spirit, they see rákyom 'twin children ghosts', and kuman-thoon the 'golden child spirit,' as children.

Normally, people pray to ph亡̌i-săantheewadaa 'good spirit' asking it to help, to prevent and to do anything that makes them feel happier. Most of the prayers concern the situations people cannot control. People also give bribes, such as a reward or a gift. The amount of the bribe depends on the degree of work.
The more difficult for the wish to come true, the bigger bribe. The following are examples of some of those ghost terms in sentences.

(14)

coon mây klâa khùt ceedii
thief not dare dig pagoda
boraan pró klua
old because afraid of
thùuk pùu-sǒom lonthôot

Passive old male spirit punish

'Thieves don't dare to dig up the old pagoda because they are afraid of püu-soom.'

(15)

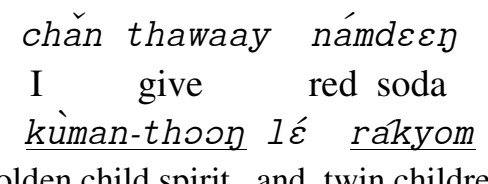
golden child spirit and twin children ghost thîuk wan pûathîi thân every day for they ca chûay hây chăn will help give I thùuk hǔay. won lottery

'I offered red-soda to kùman-thosp and rakyom everyday, so that they would help me win a lottery prize.'

With reference to ph亡̌i-hàa-saataan or phût-ph ̌̌i-piisàat 'bad spirit' twelve categories are found, as can be seen in Table 7. 
Table 7: Specific ghost categories under ph ̌̌i-hàa-saataan or phưut-ph 'bad spirit'

\begin{tabular}{|c|c|c|}
\hline \multicolumn{3}{|c|}{ Generic: phǐi-hàa-saataan or phûut-phǐi-piisàat 'bad spirit' } \\
\hline Specific & English equivalent & Meaning \\
\hline $\begin{array}{l}\text { phǐi-hàa } \\
\text { ผีห่า }\end{array}$ & $\begin{array}{l}\text { 'bad spirit causing an } \\
\text { epidemic' }\end{array}$ & $\begin{array}{l}\text { A dreadfully bad spirit dwelling in water and } \\
\text { causing an epidemic. In the past people who died } \\
\text { from cholera due to drinking infected water were } \\
\text { believed to die because of this bad spirit. }\end{array}$ \\
\hline $\begin{array}{l}\text { naay-máay } \\
\text { นางไม้ }\end{array}$ & 'female spirit of a tree' & $\begin{array}{l}\text { A female spirit dwelling in any kind of tree, } \\
\text { dressed in a white traditional Thai costume. It } \\
\text { is believed that she can harm or kill people in } \\
\text { cases where her occupied trees are cut without } \\
\text { asking for permission or without bribing her. }\end{array}$ \\
\hline $\begin{array}{l}\text { phǐi-nûak } \\
\text { ผีเงือก }\end{array}$ & 'mermaid ghost' & $\begin{array}{l}\text { A spirit that dwells in fresh water, such as a } \\
\text { pond or a river. She can harm people. Her } \\
\text { appearance is similar to that of a woman with } \\
\text { long hair. She likes combing her hair at } \\
\text { twilight. }\end{array}$ \\
\hline $\begin{array}{l}\text { prèet } \\
\text { เปรต }\end{array}$ & 'tall evil ghost' & $\begin{array}{l}\text { A tortured ghost which is extremely tall, very } \\
\text { bony and has hideously frizzy hair. It has a } \\
\text { tiny mouth of a needle's eye size. Therefore, it } \\
\text { suffers greatly from hunger because it cannot } \\
\text { eat much. Thai people believe that its existence } \\
\text { is a result of the wicked deeds it did in the past } \\
\text { and it dwells in hell. }\end{array}$ \\
\hline $\begin{array}{l}\text { yommabaan } \\
\text { ยมบาล }\end{array}$ & $\begin{array}{l}\text { 'the chief guardian of } \\
\text { hell' }\end{array}$ & $\begin{array}{l}\text { The chief ghost who is in charge of judging all } \\
\text { the dead and torturing all sinners. He has a } \\
\text { dark complexion and two long horns on this } \\
\text { head. }\end{array}$ \\
\hline $\begin{array}{l}\text { yommathûut } \\
\text { ยมทูต }\end{array}$ & 'guardian of hell' & $\begin{array}{l}\text { The ghost who works in hell. He takes a } \\
\text { human's soul to hell. }\end{array}$ \\
\hline $\begin{array}{l}\text { phǐi-rêerôn } \\
\text { ผีเร่ร่อน }\end{array}$ & 'stray ghost' & $\begin{array}{l}\text { A ghost which has no particular place to dwell. } \\
\text { It is said that this ghost used to be a wicked } \\
\text { man. }\end{array}$ \\
\hline $\begin{array}{l}\text { piisàat } \\
\text { ปีศาจ }\end{array}$ & ‘devil’ & $\begin{array}{l}\text { A hideous and terrifying demon or devil who } \\
\text { harms and haunts people. }\end{array}$ \\
\hline $\begin{array}{l}\text { ph ̌̌i-pàa } \\
\text { ผีป่า }\end{array}$ & 'jungle demon’ & $\begin{array}{l}\text { A jungle demon believed to belong to a person } \\
\text { who died in a forest. This demon cannot go } \\
\text { anywhere because he has no one to make a } \\
\text { merit for him. }\end{array}$ \\
\hline $\begin{array}{l}\text { phǐi-thalee } \\
\text { ผีทะเล }\end{array}$ & 'sea ghost' & The ghost of a person who drowned in the sea. \\
\hline
\end{tabular}




\begin{tabular}{|l|l|l|}
\hline $\begin{array}{l}\text { ph亡̌i-náam ผีน้ำ or } \\
\text { ph亡̌i-praay ผีพราย } \\
\text { or praay-náam พราย } \\
\text { น้ำ }\end{array}$ & 'water ghost' & $\begin{array}{l}\text { The water ghost of a person drowned in a } \\
\text { pond or a river. }\end{array}$ \\
\hline $\begin{array}{l}\text { ph亡̌i-taay-tháy- } \\
\text { klom ผีตายทั้งกลม or } \\
\text { ph亡̌i-taay-thóo } \\
\text { klom ผีตายท้องกลม }\end{array}$ & $\begin{array}{l}\text { 'female ghost dying } \\
\text { during pregnancy' }\end{array}$ & $\begin{array}{l}\text { A female ghost who died during pregnancy or } \\
\text { while delivering her baby. }\end{array}$ \\
\hline
\end{tabular}

All the ghost terms representing the twelve ghost categories share the same feature of being 'bad spirit.' Specifically, they are differentiated by other features, such as dwelling place, duty, gender, etc. For example, phři-hàa 'bad spirit causing an epidemic' and phřipûak 'mermaid ghost,' dwell in water, while prèet 'tall evil ghost,' yommabaan 'the chief guardian of hell,' and yommathûut 'guardian of hell,' dwell in hell. The following are examples of the specific ghost terms under the 'bad spirit' generic term.
(16) nâa náam mák dâyyin
time water often hear
sǐapróon plèck plèck
sound queer strange
khǒon phǐi-hàa
of bad spirit causing epidemic
thîi kamlay plòoy pît
that being release poison
lon náam.
fall water

'In the rainy season, we often heard

the strange sound of phrì-hàa

releasing poison into the water.'
(17) naạ-máay cà tham female spirit of a tree will make ráay khon thîi may khoo hurt person who not ask Pànúyâat kòon tàt máay. permit before cut down tree 'naan-máay will hurt anyone who cuts down the tree without permission.'

(18) kray thûp tii pôo anyone hit beat (his) father $m \hat{\varepsilon} \mathcal{\varepsilon}$ mûa taay cà mother when(he) die will klaaypen prèet. become evil tall ghost

'Anyone who hurts his parents will turn into prèet when he passes away.'

(19)

Pyàa lên nám naay
do not play water in
weelaa khlaay khuumn
time middle night
phı̌i -praay cà dury
water ghost will pull
khăa tham-hây raw com
legs make us drown
náam taay.
water die
'Don't play in the water at night. The
'water ghost' will drown us.'


(20)

thâa mây Pyàak thùuk

If not want passive

phǐi-pàa khâa taay

jungle demon kill die

tóon sùat-mon kòon

must pray before

khâw pàa thûk khrán.

enter jungle every time

'If you don't want to be killed by

the 'jungle demon,' you have to

pray every time before you enter the jungle.'

Table 8: Specific ghost categories under the generic phíi-dùut-lûat 'blood sucking ghost'

\begin{tabular}{|c|c|c|}
\hline \multicolumn{3}{|c|}{$\begin{array}{c}\text { Specific: phǐi-dùut-lûat 'blood sucking } \\
\text { ghost' }\end{array}$} \\
\hline $\begin{array}{c}\text { Variet } \\
\text { al }\end{array}$ & $\begin{array}{c}\text { English } \\
\text { equivalent }\end{array}$ & Meaning \\
\hline $\begin{array}{l}p h i \check{i}- \\
\text { dìp } \\
\text { ผีดิบ }\end{array}$ & $\begin{array}{l}\text { 'uncremated } \\
\text { ghost' }\end{array}$ & $\begin{array}{l}\text { A Chinese court } \\
\text { ghost recognized by } \\
\text { its heavy bouncing } \\
\text { instead of walking. } \\
\text { The word dip means } \\
\text { 'raw.' This kind of } \\
\text { ghost has not been } \\
\text { cremated. }\end{array}$ \\
\hline $\begin{array}{l}d r \hat{\varepsilon} k- \\
k h i w- \\
l \hat{a} a^{5} \\
\text { แดร็กคิว } \\
\text { ลา }\end{array}$ & 'dracula' & $\begin{array}{l}\text { A blood drinking } \\
\text { demon whose sucks } \\
\text { blood from a victim, } \\
\text { who will soon } \\
\text { become another } \\
\text { demon like him. He } \\
\text { hates garlic and } \\
\text { sunlight. }\end{array}$ \\
\hline
\end{tabular}

${ }^{5}$ This term $d r \hat{\varepsilon} k-k h i w-l a ̂ a$ 'dracula' is the borrowed from the Western term.
As shown in Table 8, neither $d r \hat{\varepsilon} k$-khiwlâa 'dracula' nor phǐi-dìp 'uncremated ghost' appear in daylight. They are both considered sub-categories of phíi-dùutlûat 'blood sucking ghost' as can be seen in the following examples.

(21) chăn hěn

I see

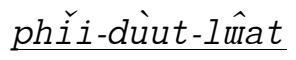

ghost that drinks people's blood

pleEnrâa pen

transfigure be

kháankhaaw bin nìi

bat fly escape

pay man cà tồn pen

away it will must be

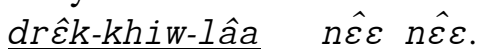

Dracula sure sure

'I saw phǐi-dùut-I ûat change into a bat and fly away. It must be dracula.'

phï dìp chôop

uncremated ghost like

dùut lîut càak lamkhoo

drink blood from neck

khǒon dغ̇k.

of children

'The uncremated ghost likes drinking blood from children's necks.' 


\section{The fifth level: varietal}

The last level of the folk taxonomy of ghost terms in Thai is the varietal level. There are only six categories in this last level. Four of them are sub-categories of naay-máay 'female spirit of a tree,' and two are under theewadaa 'angel.'
Table 9 shows varietal categories under naay-máay 'female spirit of a tree' and Table 10 shows varietal categories under theewadaa 'angel.'

Table 9: Varietal ghost categories under the specific naay-máay 'female spirit of a tree'

\begin{tabular}{|c|c|c|}
\hline \multicolumn{3}{|c|}{ Specific: naaฤ-máay 'female spirit of a tree' } \\
\hline Varietal & English equivalent & Meaning \\
\hline $\begin{array}{l}\text { naap-tàkhian } \\
\text { นางตะเคียน }\end{array}$ & $\begin{array}{l}\text { 'female spirit of a } t a- \\
\text { khian tree' }\end{array}$ & $\begin{array}{l}\text { A female spirit who dwells in Malabar } \\
\text { ironwood. She is dressed in a white } \\
\text { traditional Thai costume. It is believed that } \\
\text { she can haunt and hurt people. She can even } \\
\text { kill or possess a person so as to make him } \\
\text { insane. }\end{array}$ \\
\hline $\begin{array}{l}\text { naay-taanii } \\
\text { นางตานี }\end{array}$ & $\begin{array}{l}\text { 'female spirit of a } \\
\text { banana tree' }\end{array}$ & $\begin{array}{l}\text { A female spirit dwelling in a banana tree. } \\
\text { She is dressed in a greenish traditional Thai } \\
\text { costume. It is said that a man who courts } \\
\text { her affectionately for three days will get her } \\
\text { as a wife. However, if he treats her badly, } \\
\text { she will break his neck and kill him. }\end{array}$ \\
\hline $\begin{array}{l}c \hat{a} a w-m \hat{\varepsilon} \varepsilon-s a y \\
\text { เจ้าแม่ไทร }\end{array}$ & $\begin{array}{l}\text { 'female spirit of a } \\
\text { banyan tree' }\end{array}$ & $\begin{array}{l}\text { A female spirit who dwells in a banyan tree } \\
\text { She is respected and offered bribes by those } \\
\text { who have faith in her. A Thai style shrine is } \\
\text { erected for her dwelling and as a symbol of } \\
\text { respect for her. }\end{array}$ \\
\hline $\begin{array}{l}c \hat{a} a w-m \hat{\varepsilon} \mathcal{E}-m a ́ k h a ̌ a m \\
\text { เจ้าแม่มะขาม }\end{array}$ & $\begin{array}{l}\text { 'female spirit of a } \\
\text { tamarind tree' }\end{array}$ & $\begin{array}{l}\text { A female spirit who dwells in a tamarind } \\
\text { tree. She is bribed by people, who also } \\
\text { establish a spirit house for her. }\end{array}$ \\
\hline
\end{tabular}

As shown in Table 9 the four varietal terms representing the four sub-categories of naay-máay 'female spirit of a tree' share the same important features[+spirit of a tree], and [+female] but they still differ from each other by the characteristic of their dwelling in different kinds of tree. For instance, naay-tàkian signifies a female spirit dwelling in the $t a-$ khian tree, naay-taanii dwelling in a

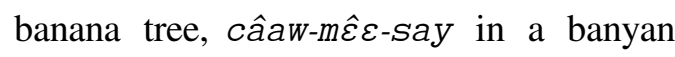

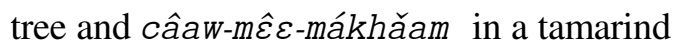
tree.

Because they are under the generic level of

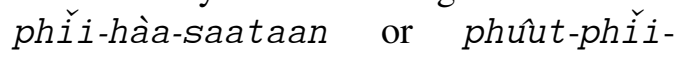
piisàat 'bad spirit,' Thai people see them as malevolent spirits who dwell in trees, as shown in the following examples. 
(23)

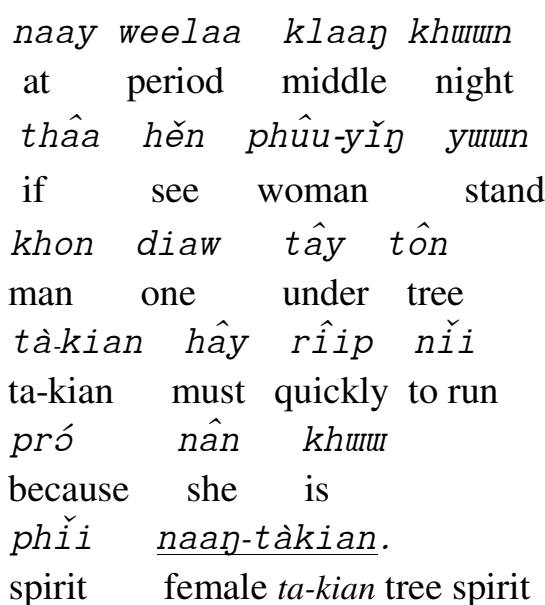

'At night, if you see a woman standing alone under the ta-kian tree, you must run away because she is a spirit of the ta-kian tree.'

(24)

Pyàa plùuk tôn klûay
do not plant tree banana

taanii nay khèet bâan

taa-nii in area home

pôonkan naan-taanii

protect female banana tree spirit

cà ma tham ráay raw.

will come make hurt us

'Don't plant ta-nii banana tree in the home area because the spirit of the banana tree will come and hurt us.'

Under the specific term theewadaa 'angel' there are two varietal categories: thêep -thídaa or naayfáa 'female deity' and thêep 'male deity'; thêep -thídaa or naan-fáa 'female deity' is female, while thêep 'male deity' is male, as shown in Table 10.
Table 10: Varietal ghost categoriess under the specific theewadaa 'angel'

\begin{tabular}{|l|l|l|}
\hline \multicolumn{3}{|c|}{ Specific: theewadaa 'angel' } \\
\hline \multicolumn{1}{|c|}{ Varietal } & $\begin{array}{c}\text { English } \\
\text { equivalent }\end{array}$ & \multicolumn{1}{|c|}{ Meaning } \\
\hline $\begin{array}{l}\text { thêep - } \\
\text { thídaa } \\
\text { เทพธิดา } \\
\text { or naap- } \\
\text { fáa นางฟ้า } \\
\text { deity' }\end{array}$ & $\begin{array}{l}\text { A female deity } \\
\text { who has a } \\
\text { beautiful and } \\
\text { seductive physical } \\
\text { appearance and } \\
\text { dwells blissfully in } \\
\text { heaven. }\end{array}$ \\
\hline $\begin{array}{l}\text { thêep } \\
\text { เทพ }\end{array}$ & 'male & $\begin{array}{l}\text { A male deity who } \\
\text { has a handsome } \\
\text { and seductive } \\
\text { physical } \\
\text { appearance. He } \\
\text { dwells with } \\
\text { extreme joy in } \\
\text { heaven. }\end{array}$ \\
\hline
\end{tabular}

The term thêep-thídaa or naay-fáa 'female deity' shares the same characteristics with thêep 'male deity' that is [+good spirit in heaven] and Thai people respect them. It is believed that if we regularly make merit and behave well, we will be born again as a thêep 'male deity,' or thêep -thídaa 'female deity.' This shows that Thai people have faith in life after death, as seen in the following sentence.

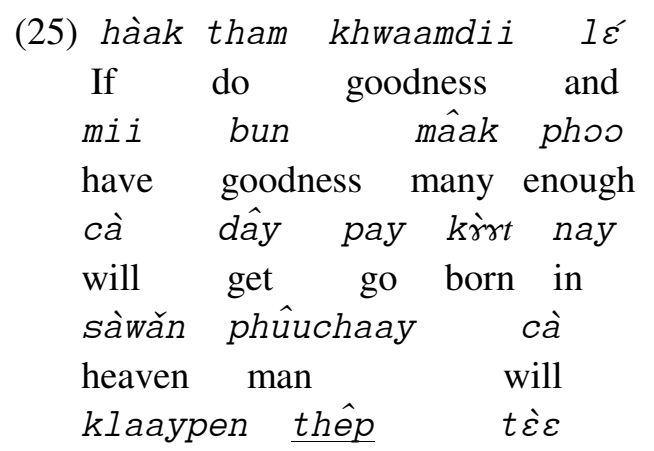




become male deity but
phûuyín cà klaaypen
woman will become
thêep-thídaa rǔut
female deity or
naan-fáa.
female deity
'If you are good and make enough
merit, you will be born again in
heaven. The man will become
a thêep and the woman will become
a thêep-thídaa or naan-fáa.'

\section{Conclusion}

In the preceding pages, we have shown a system of ghosts and spirits in Thai culture. It resulted from an ethnosemantic analysis of ghost terms in Thai. The findings shown here are an arrangement of all the ghost terms into a folk taxonomy of five levels based on Berlin (1992): unique beginner, life form, generic, specific and varietal. Our decision as to which terms refer to which levels of the taxonomy depends on the semantic features of the ghost terms elicited from informants who are native speakers of Central Thai. Also, the placement of each term in the hierarchy is also based on the suggestion whether the term contrasts with another term or is included in it. In brief, our conclusion is not based on our own logical thinking or scientific knowledge but on the folk world view.

The findings imply that Thai people are close to nature. Indeed, most ghost terms show that ghosts have fixed dwellings, for example, trees, rivers, mountains, forests, rice fields, etc.

It has been found that only female ghost terms have titles as part of their structure, such as naay 'female title' and $m \hat{\varepsilon} \varepsilon$ 'mother' which marks the female gender e.g. naay-máay 'female tree spirit', naaytaani i 'female banana tree spirit', naaytakian 'female spirit of a kind of tree

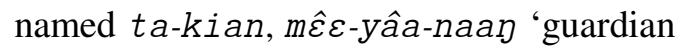
goddess of boats', $m \hat{\varepsilon} \varepsilon$-phoosòp 'goddess of rice' and $m \hat{\varepsilon} \mathcal{E}$-thooranii 'goddess of the land' etc. The findings show that terms with naay- signify bad spirits and those with $m \hat{\varepsilon} \mathcal{E}$ - good spirits. Also, it may be interesting to note that all male ghost terms are unmarked; they do not begin with a title.

In conclusion, the analysis of ghost terms presented in this study reveals the Thai cognition of ghost system. It also implies that in that Thai cognition, ghosts do exist because there are ghost terms to represent them. Although they cannot be seen, people perceive that they are all around.

\section{References}

Berlin, Brent. 1992. Ethnobiological classification: principles of categorization of plants and animals in traditional societies. Princeton, N.J.: Princeton University Press.

Berlin, Brent, Breedlove, Dennis and Raven, Peter. 1973. General Principles of Classification and Nomenclature in Folk Biology. American Anthro pologist 75: 214-242.

Frake, Charles O. 1961. Diagnosis of disease among the Subanun of Mindanao. American Anthropologist 63: 113-132. 
Panyaatisin, Kosin. 2009. An ethnosemantic study of cooking terms in Northern Thai (การศึกษาคำเรียกการ ทำอาหารในภาษาไทยถิ่นเหนือตามแนวอรรถศาสตร์ ชาติพันธุ์). M.A. thesis in Linguistics (วิทยานิพนธ์ปริญญามหาบัณฑิต).

Chulalongkorn University, Bangkok (In Thai)

Phaithayawatthana, Saowapa.1995. Foundations of Thai culture: Ways of conservation and development (พื้นฐาน วัฒนธรรมไทย: แนวทางอนุรักษ์และการพัฒนา). กรุงเทพมหานคร หน่วยศึกษานิเทศก์ สำนักงานสภาสถาบันราชภัฏ. (In Thai)

Prasithrathsint, Amara. 2001. The componential analysis of kinship terms in Thai. In Essays in Tai Linguistics, edited by M.R. Kalaya Tingsabadh and Arthur Abramson. Bangkok:

Chulalongkorn University Press.

Prasithrathsint, Amara. 2006.

Ethnosemantic. (อรรถศาสตร์ชาติพันธุ์: วิธี การศึกษาภาษาเพื่อเข้าสู่ระบบปริชานของมนุษย์). In Making of a linguist (จนกว่าจะเป็น นักภาษาศาสตร์). Bangkok: Department of Linguistics,Chulalongkorn University ภาควิชาภาษาศาสตร์ จุฬาลงกรณ์มหาวิทยาลัย จัดพิมพ์เนื่องในโอกาสเกษียณอายุราชการ ศาสตราจารย์ ดร. อมรา ประสิทธิ์รัฐสินธุ์. (In Thai)
Pumyoo, Watit. 2005. An ethnosemantic study of rice terms and the conceptual system of rice in Southeast Asian languages (การศึกษาคำเรียกข้าวและระบบมโน ทัศน์เรื่องข้าวในภาษาเอเชียตะวันออกเฉียงใต้ตาม แนวอรรถศาสตร์ชาติพันธุ์). M.A. thesis in Linguistics (วิทยานิพนธ์ปริญญามหาบัณฑิต) Chulalongkorn University, Bangkok (In Thai)

The Fine Arts Department.1984. Sukhothai stone inscriptions (จารึกสมัยสุโขทัย). Bangkok: Fine Arts Department (กรมศิลปากร). กรุงเทพมหานคร: กรมศิลปากร.

(In Thai) 